I 34 m US-CE-C

1. $5-72-20$

ap. 3

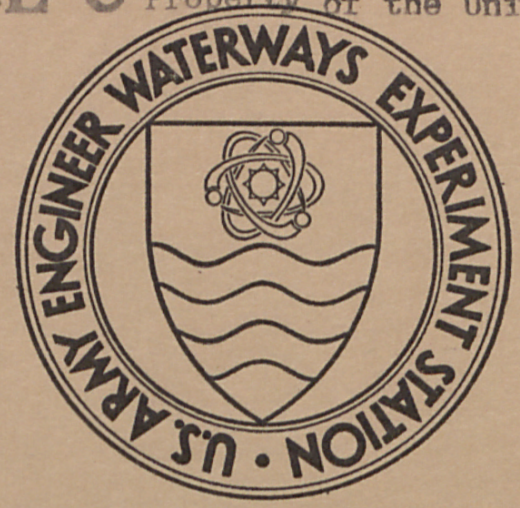

MISCELLANEOUS PAPER S-72-20

\title{
CONDITION SURVEY, DAVISON ARMY AIRFIELD, FORT BELVOIR, VIRGINIA \\ by
}

P. J. Vedros, R. D. Jackson

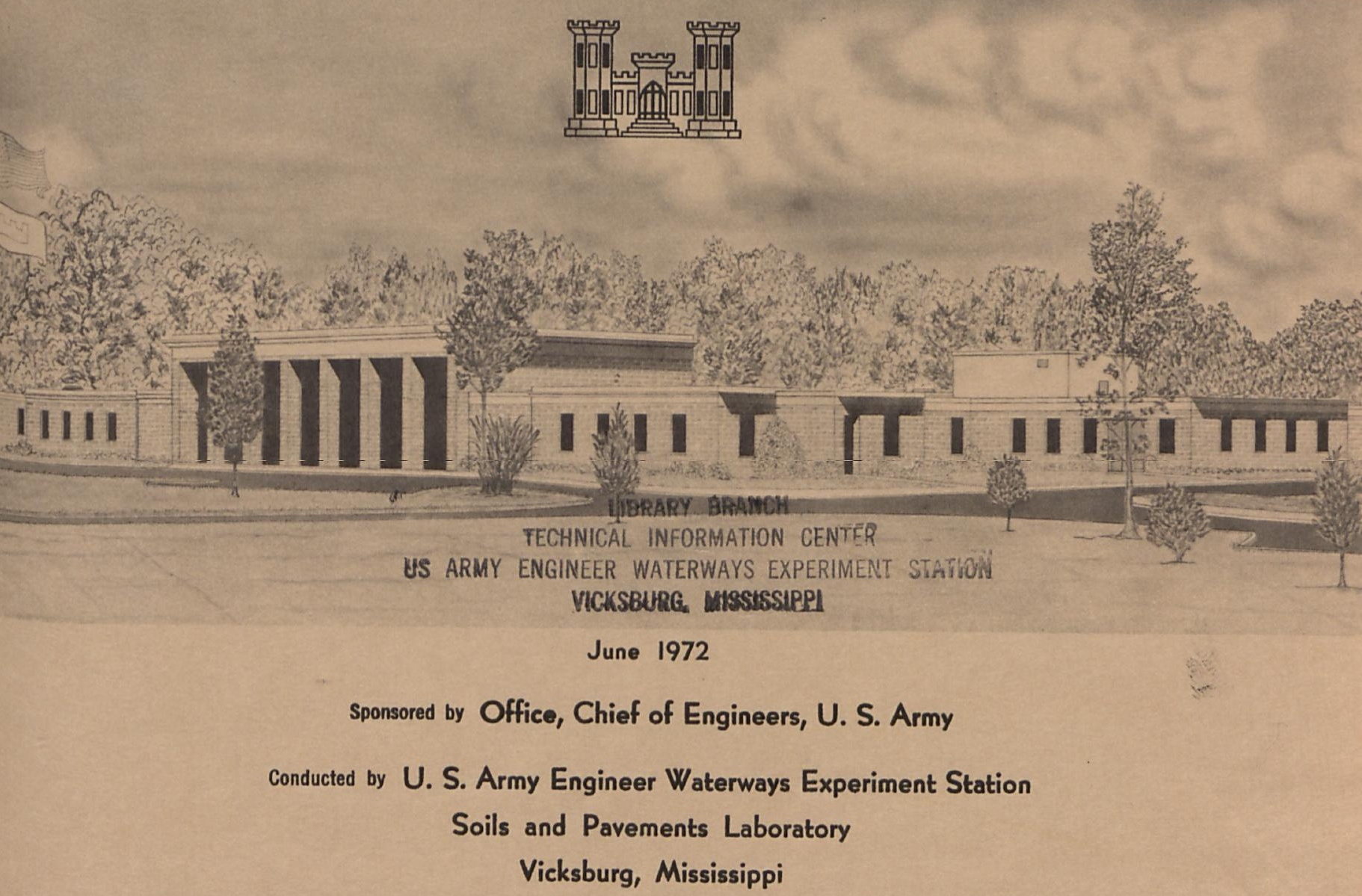




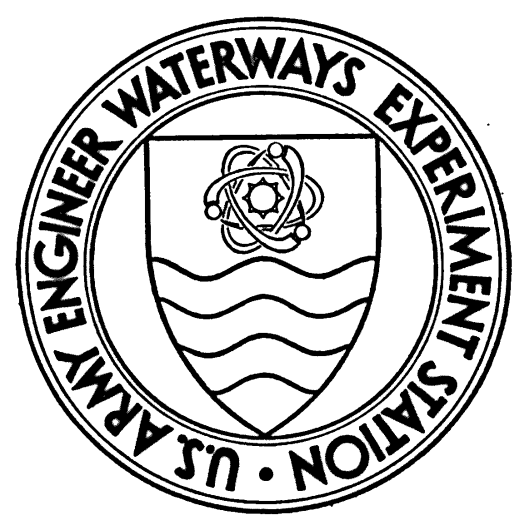

MISCELLANEOUS PAPER S-72-20

\section{CONDITION SURVEY, DAVISON ARMY AIRFIELD, FORT BELVOIR, VIRGINIA \\ by}

P. J. Vedros, R. D. Jackson

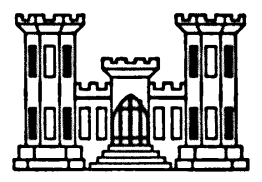

June 1972

Sponsored by Office, Chief of Engineers, U. S. Army

Conducted by U. S. Army Engineer Waterways Experiment Station

Soils and Pavements Laboratory

Vicksburg, Mississippi 


\section{Foreword}

Authority for performance of condition surveys at selected airfields is contained in Long-Range Program, O\&M,A, FY 1971, Project Q6-1: "Engineering Criteria for Design and Construction - WES," dated 1 July 1971.

The facilities at Davison Army Airfield were inspected in August 1971 by $\mathrm{Mr}$. R. D. Jackson of the General Engineering Support Branch, U. S. Army Engineer Waterways Experiment Station (WES). This report was prepared by Messrs. Jackson and P. J. Vedros under the general supervision of Messrs. J. P. Sale, R. G. Ahlvin, and R. L. Hutchinson of the Soils and Pavements Laboratory, WES.

COL Ernest D. Peixotto, CE, was Director of the WES during the conduct of the study and preparation of this report. Mr. F. R. Brown was Technical Director. 


\section{Contents}

$\underline{\text { Page }}$

Foreword ........................ 1 . . . .

Conversion Factors, British to Metric Units of Measurement . . . . vii Purpose .......................... 1

Pertinent Background Data ................. 1

General description of airfield ............. 1

Previous reports ................ 2

History of Airfield Pavements ............... 2

Fixed-wing facilities . . . . . . . . . . . . 2

Rotary-wing facilities .............. 3

Traffic history ... . . . . . . . . . . . . 3

Airfield Maintenance .. . . . . . . . . . . . . . 4

Condition of Pavement Surfaces ................ 4

Evaluation ...................... 5

Tables 1 and 2

Photographs 1-7

Plate 1 
Conversion Factors, British to Metric Units of Measurement

British units of measurement used in this report can be converted to metric units as follows:

\begin{tabular}{llll}
\cline { 3 - 3 } inches & 2.54 & & centimeters \\
feet & 0.3048 & meters \\
miles (U. S. statute) & 1.609344 & kilometers \\
pounds & 0.45359237 & kilograms \\
pounds per square inch & 0.6894757 & newtons per square centimeter
\end{tabular}




\section{CONDITION SURVEY, DAVISON ARMY AIRFIELD}

FORT BELVOIR, VIRGINIA

\section{Purpose}

1. The purpose of this report is to present the results of an inspection performed at Davison Army Airfield (DAAF) in August 1971. The inspection was limited to visual observations, and no tests were conducted on the existing runways and taxiways. A layout of the airfield is shown in plate 1.

\section{Pertinent Background Data}

General description of airfield

2. DAAF is located in the northwest part of Fort Belvoir in Fairfax County, Virginia, approximately 20 miles* south of the center of Washington, D. C.

3. The airfield is in the embayed section of the Coastal Plain province. The surface soils in the area occupied by the airfield are of alluvial origin, consisting mostly of sandy clay. Some of the area in the vicinity of the airfield is underlain by water-bearing strata; the water sometimes rises to the surface. The topography in the immediate vicinity consists of a rolling relief sloping northeastward with elevations ranging from approximately 40 to $80 \mathrm{ft} \mathrm{msl}$.

4. In August 1971, the airfield consisted of facilities for both fixed- and rotary-wing aircraft. The fixed-wing facilities-consisted of a 4000- by 75-ft runway, connecting taxiways, parking apron, run-up apron, and a compass swing base with connecting taxiway. Two rotary-wing areas, utilized by U. S. Army Mobility Equipment Research and Development Center (MERDC) and U. S. Army Engineer Development Laboratory (EDL), are located

* A table of factors for converting British units of measurement to metric units is presented on page vii. 
on the fixed-wing side of the field. On the northeast side of the field, the rotary-wing facilities consist of a heliport with two runways, connecting taxiways, and a parking apron. Also located on the northeast side is a parking area for aircraft near the northwest end of the fixed-wing runway. Previous reports

5. Previous reports covering the airfield facilities are 1isted below, and pertinent data were extracted from them for use in this condition survey report.

a. Condition survey report. U. S. Army Engineer Waterways Experiment Station, CE, "Condition Survey, Davison Army Airfield, Fort Belvoir, Virginia," Miscellaneous Paper S-68-26, November 1968, Vicksburg, Miss.

b. Evaluation report. U. S. Army Engineer Waterways Experiment Station, CE, "Army Airfield Pavement Evaluation, Davison Army Airfield, Fort Belvoir, Virginia," Technical Report No. 3-466, Report 2, October 1957, Vicksburg, Miss.

\section{History of Airfield Pavements}

\section{Fixed-wing facilities}

6. As stated in the report referenced in paragraph $5 \underline{b}$, the exact date of the construction of the runway, taxiway, and asphaltic concrete (AC) parking apron could not be determined, but construction was accomplished as a training program for engineer troops over a period of years. The facilities were initially surfaced with approximately $2 \mathrm{in}$. of asphaltic concrete over a 3- to 10-in. gravel base course. The overrun at the northwest end of the runway was surfaced with a bituminous surface treatment. During the original construction program, a refueling apron was constructed of 7-in.-thick portland cement concrete (PCC) over the natural clayey subgrade (plate 1). The pavement was designed for a 28-day flexural strength of 550 psi. In August 1956, the runway and taxiways were overlaid with approximately 2 in. of AC. In 1959 the fixed-wing parking apron was extended, and construction drawings indicate construction consisted of 10-in.-thick PCC over $16 \mathrm{in.}$ of select base course material. Pavement design was for a 28-day flexural strength of 560 psi. In 1960 a parking apron, connecting 
taxiway, and washrack were constructed for MERDC (then U. S. Army Engineer Research and Development Laboratories) operations (plate 1). The apron and Taxiway consisted of 2-in. AC surface over 8-in. stabilized aggregate base course. The washrack was paved with 6 in. of PCC over a 6-in. stabilized aggregate base course. In 1969 the parallel taxiway width was increased to $40 \mathrm{ft}$ and the entire taxiway and the runway were overlaid with 1 in. of AC. At the time of this inspection, some new pavements had been constructed but were not being used because the shoulders and striping had not been completed. Typical sections for the new pavements are shown in plate 1. These pavements include $635 \mathrm{ft}$ of the northwest end of the fixed-wing runway, connecting taxiways, a run-up apron, and a compass swing base. The $635 \mathrm{ft}$ of the runway, the taxiways, and the run-up apron consist of 2 in. of AC over 6 in. of stabilized aggregate base course and 10 in. of select material subbase (section A-A, plate 1). The compass swing base pavement is $9 \mathrm{in}$. of PCC over $4 \mathrm{in}$. of a stabilized aggregate base course (section $B-B$, plate 1 ). Specifications require a 28-day flexural strength of 550 psi for the PCC pavement. Rotary-wing facilities

7. The rotary-wing or heliport facilities located on the northeast side of the field consisted of a parking apron, two runways, and connecting taxiways. These facilities were constructed in 1960. The parking apron and taxiways consisted of 9-in.-thick PCC over 9 in. of select material. Design requirements for these pavements were a 28-day flexural strength of $550 \mathrm{psi}$ and a subgrade modulus of $200 \mathrm{lb}$ per sq in. per in. of deflection. The construction for the taxiways consisted of 2-in. AC over a 7-in. stabilized aggregate base course and 4-in. select material subbase course. Traffic history

8. Traffic records obtained from the Signal Corps for the period May 1957 to June 1966 at DAAF are shown in the following tabulation. As can be noted, the traffic activity count is given as rotary-wing and fixed-wing aircraft (types and loads not indicated). The majority of the traffic is light aircraft of less than 10,000-1b gross load with occasional traffic by heavier aircraft. 


\begin{tabular}{ccc} 
Period & Fixed-Wing & Rotary-Wing \\
\cline { 2 - 3 } May-Dec 1957 & 10,360 & 10,621 \\
1958 & 28,963 & 19,126 \\
1959 & 47,974 & 29,292 \\
1960 & 47,740 & 25,233 \\
1961 & 47,341 & 26,175 \\
1962 & 39,658 & 53,743 \\
1963 & 32,465 & 46,385 \\
1964 & 37,090 & 58,270 \\
1965 & 43,308 & 71,274 \\
Jan-Jun 1966 & 17,349 & 31,164
\end{tabular}

Traffic records were not available for the period July 1966-June 1970. However, traffic for the period 1 July 1970 to 30 June 1971 consisted of 76,124 movements of fixed-wing and 70,601 rotary-wing aircraft. A movement constitutes any operation, such as practice landing, touch-and-go, etc.

\section{Airfield Maintenance}

9. Maintenance on the airfield since 1967 has been limited to the $1-$ in. AC overlay on the fixed-wing runway and taxiways in 1969.

\section{Condition of Pavement Surfaces}

10. In August 1971, the AC surface on the runway was considered to be in good condition (photograph 1) except for two small localized areas. Photograph 2 shows a distress area, typical of a base or subgrade failure, located approximately at runway sta $3+25$. The apparent cause is the presence of subsurface water. A patched area approximately at runway sta $8+50$ is shown in photograph 3. Note the white deposit on the surface adjacent to the patch, which was apparently caused by water ponded on the runway. Personnel at the base were of the opinion that this water originated from springs below the level of the base course. Photograph 4 shows a paving lane joint of the new runway extension approximately at sta $37+00$. The parallel taxiway surface appeared to be in good condition (photograph 5). The AC portion of the fixed-wing parking apron appeared to be in good condition (photograph 6) even though some minor cracking was noted. The PCC 
pavements of the fixed-wing facilities appeared to be in excellent condition with only a very small number of minor defects. The rotary-wing PCC pavement facilities appeared to be in good structural condition. The joint-filler material of these facilities had hardened considerably. There was some surface spalling along a few of the joints (photograph 7) that could have been caused by snow-removal equipment.

\section{Evaluation}

11. The evaluation has been revised to reflect the 1969 AC overlay of the runway and taxiway. The loads shown in tables 1 and 2 were determined using the pavement sections and CBR values selected in the 1957 report and the reported design values and overlay thicknesses for new and overlaid pavements. As can be noted in table 1, the basic field evaluation is controlled by the load-carrying capacity of the fixed-wing taxiway, which had a pavement section consisting of $5 \mathrm{in}$. of $A C$ and 3 -in. base course (CBR of 25) over the subgrade (CBR of 8). The flexible pavement portion of the fixed-wing parking apron had a lower evaluation than the taxiway but was not considered in the basic evaluation, since the rigid pavement portion could be used for parking aircraft. 
Table 1

Summary of Basic Evaluation

\begin{tabular}{|c|c|c|c|c|c|}
\hline \multirow[b]{2}{*}{$\begin{array}{l}\text { Pavement Identification } \\
\text { (Primary Use Pavements) }\end{array}$} & \multicolumn{4}{|c|}{ Allowable Gross Aircraft Loading in Pcunds } & \multirow[b]{2}{*}{ Remarks } \\
\hline & $\begin{array}{l}\text { Normal Period } \\
\text { Single-Wheel } \\
\text { Gear } \\
\end{array}$ & $\begin{array}{c}\text { Evaluation } \\
\text { Twin-Wheel } \\
\text { Gear } \\
\end{array}$ & $\begin{array}{l}\text { Frost-Melting } \\
\text { Single-Wheel } \\
\text { Gear }\end{array}$ & $\begin{array}{l}\text { Evaluation } \\
\text { Twin-WheeI } \\
\text { Gear } \\
\end{array}$ & \\
\hline \multicolumn{6}{|c|}{ Fixed-Wing Airfield Pavements } \\
\hline Runway & 24,000 & 40,000 & (a) & (a) & \\
\hline Taxiways & 14,000 & 21,000 & (a) & (a) & Basic evaluation \\
\hline Parking apron (flexible) & 8,500 & 17,000 & (a) & (a) & \\
\hline Parking apron (rigid) & $60,000+$ & $50,000+$ & 58,000 & $50,000+$ & \\
\hline \multicolumn{6}{|c|}{ Heliport Pavements } \\
\hline Runways & 48,000 & $50,000+$ & 43,000 & 50,000 & \\
\hline Parking apron & 48,000 & $50,000+$ & 43,000 & 50,000 & \\
\hline
\end{tabular}

NOTE: (a) denotes allowable gross loading less than 5,000 lb.

Plus sign denotes allowable gross loading greater than the maximum gross weight of any existing aircraft having indicated gear configuration. 
Table 2

Summary of Pavement Evaluation for Overload Aircraft

(Basic field evaluation: 14,000-1b gross wt for single wheel and 21,000-1b gross wt for twin whee1)

\begin{tabular}{|c|c|c|c|c|c|}
\hline \multicolumn{3}{|c|}{ Overload Aircraft } & \multicolumn{3}{|c|}{ A1lowable Gross Aircraft Load, 1b } \\
\hline & & $1 b$ & One Cycle & One Cycle & One Cycle \\
\hline Type Aircraft & Empty & Gross & Per Day & Per Week & Per Month \\
\hline$C-47$ & 17,900 & 33,000 & 20,000 & 25,000 & 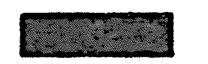 \\
\hline C-123 & 30,000 & 60,000 & Q7ZZד & Q717Z & 42,000 \\
\hline$C-131$ & 30,700 & 60,000 & DZ77ד & 39,000 & \\
\hline$C-119$ & 41,000 & 77,000 & 27172 & Q7Z7ZA & 60,000 \\
\hline$c-54$ & 39,000 & 82,500 & QZZZA & 39,000 & 60,000 \\
\hline$C-130$ & 57,300 & 135,000 & Q7ZZZ & 62,000 & 85,000 \\
\hline C-124 & 100,700 & 216,000 & EZIZA & QZZZZ & EDZZA \\
\hline$C-141$ & 134,000 & 316,600 & QZ7ZZ & EZZZA & QRZDA \\
\hline C-5A & 318,200 & 770,000 & DZZZA & EZZZA & DZZ7Z \\
\hline
\end{tabular}

NOTE: Operations with overload aircraft will be restricted during frost-melting period.

QZ7Z Evaluation is less than empty weight of aircraft.

20,000 Aircraft can operate at load indicated.

Aircraft can operate at maximum gross load. 


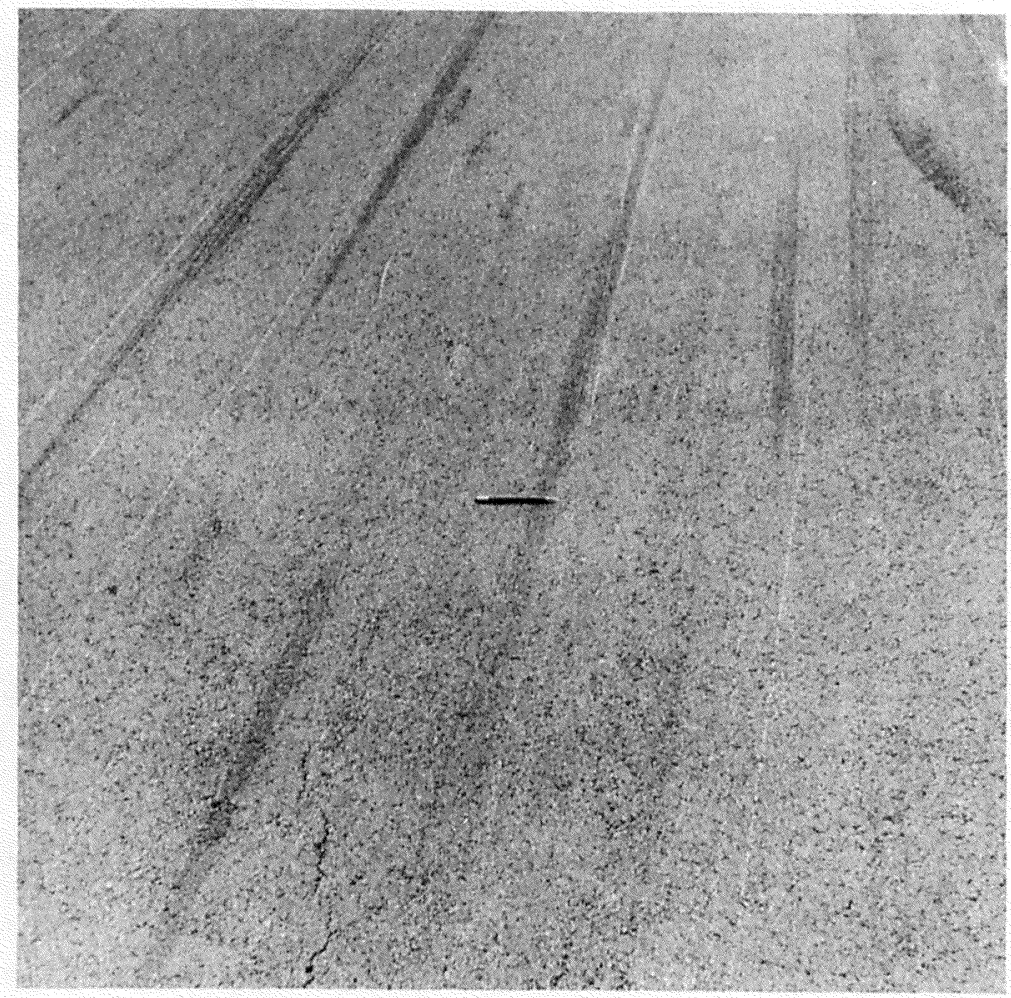

Photograph 1. Typical surface condition of runway

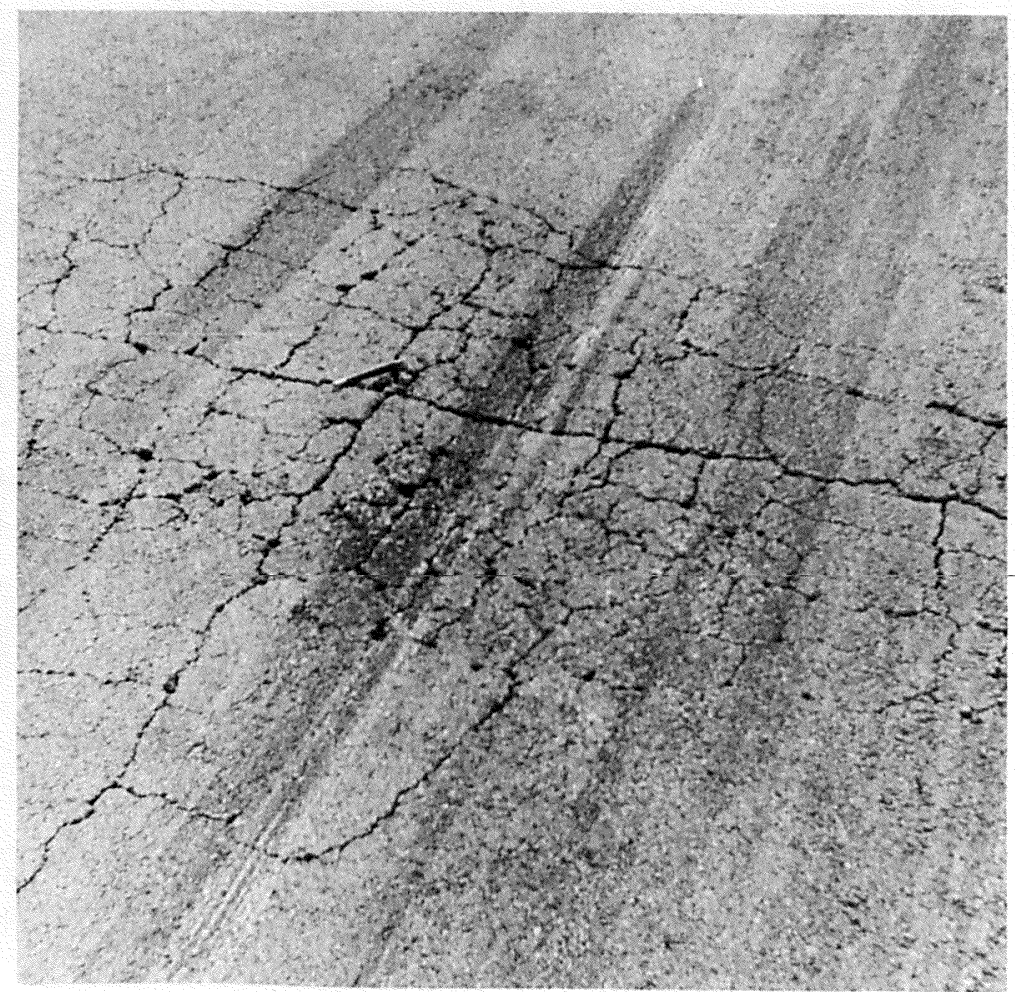

Photograph 2. Failed area on runway at sta $3+25$ 


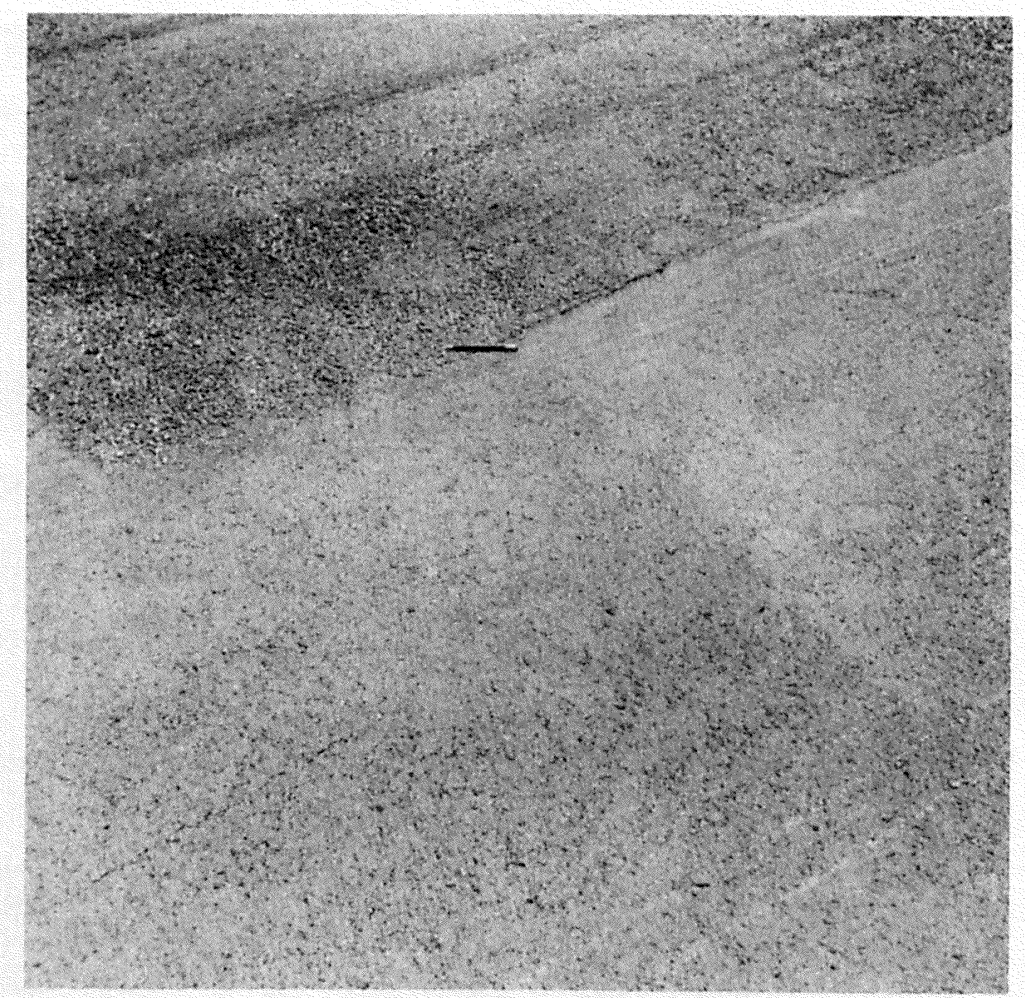

Photograph 3. Patched area at sta $8+50$

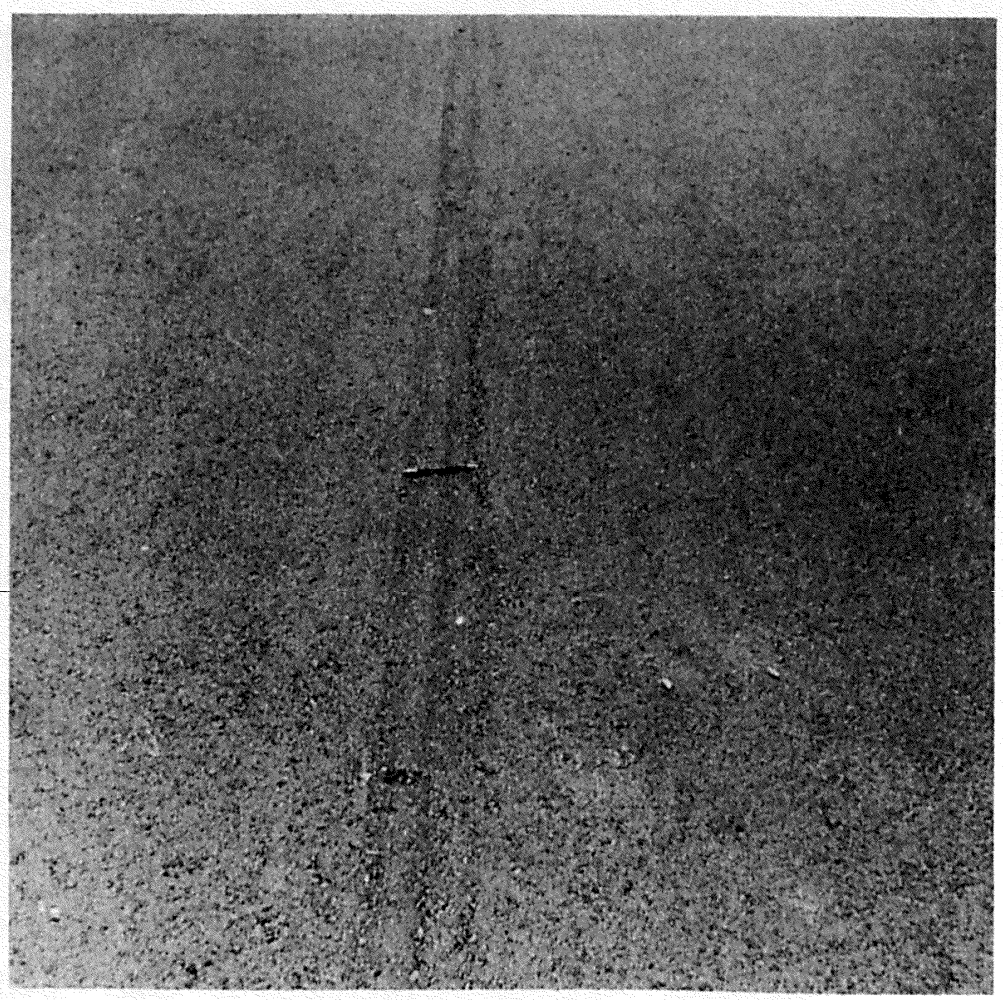

Photograph 4. Paving lane joint of new construction at sta $37+00$ 


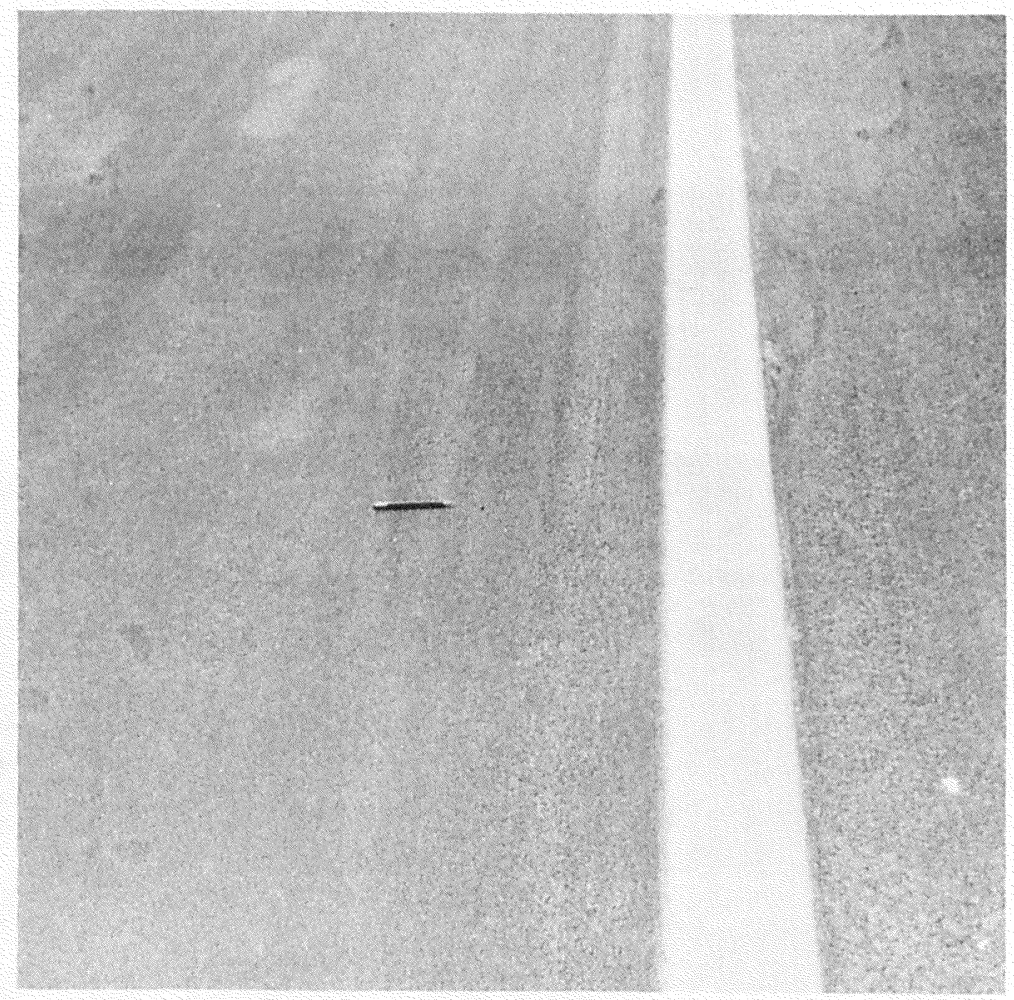

Photograph 5. Typical surface condition of fixed-wing taxiway

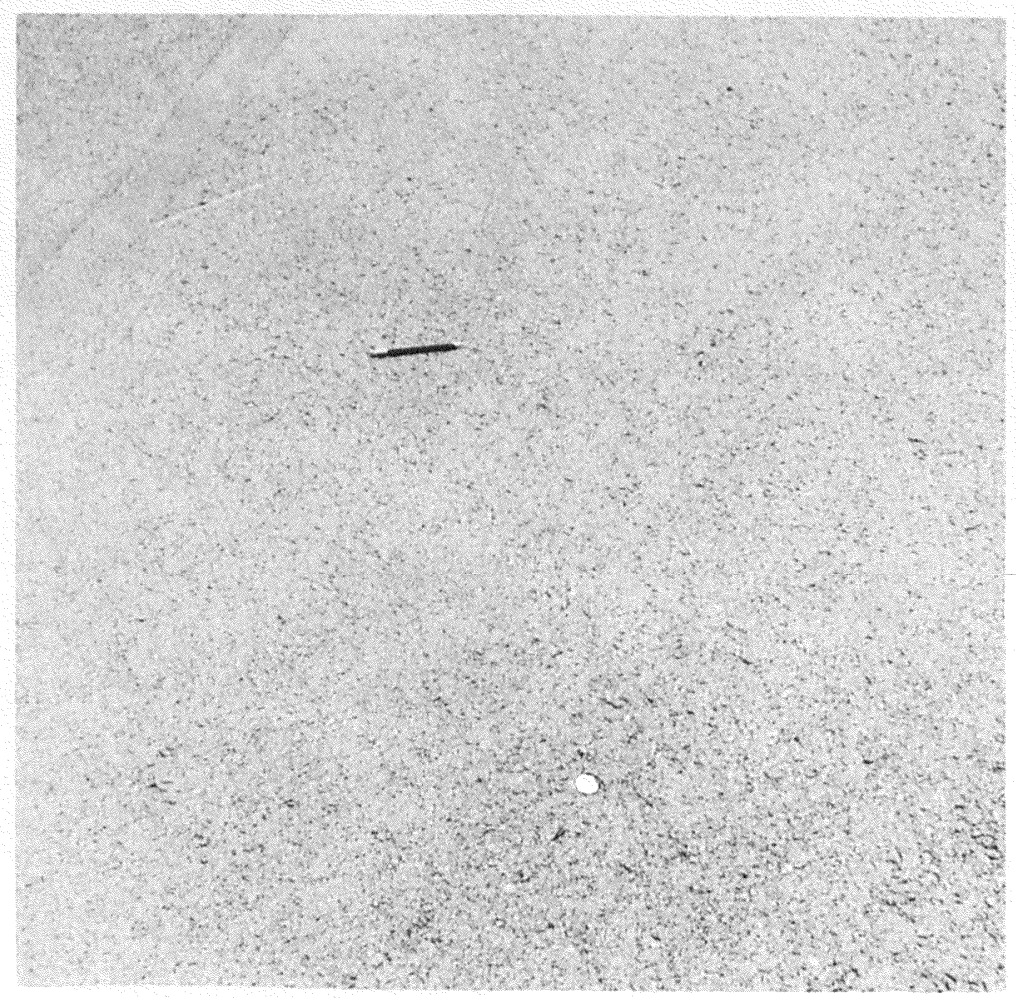

Photograph 6. Typical surface condition of flexible portion, fixed-wing apron 


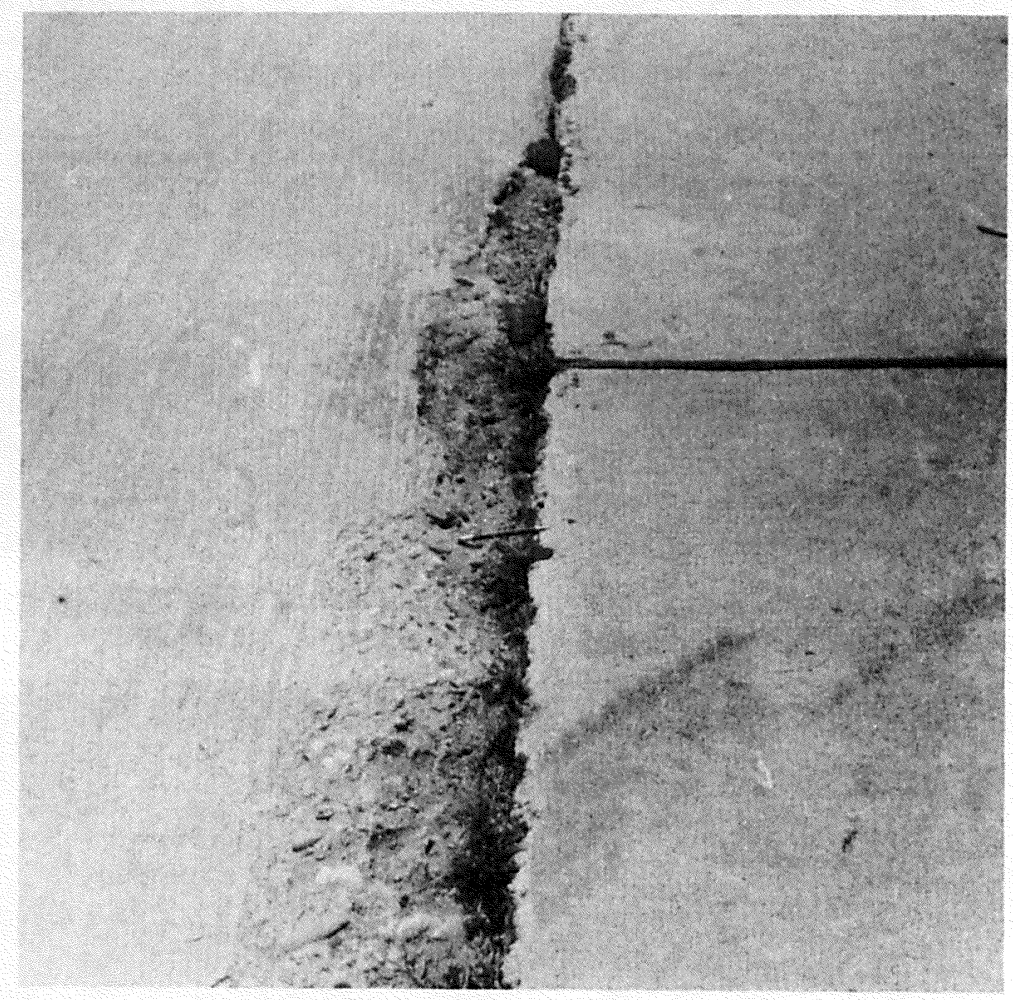

Photograph 7. Joint spall on rotary-wing apron 


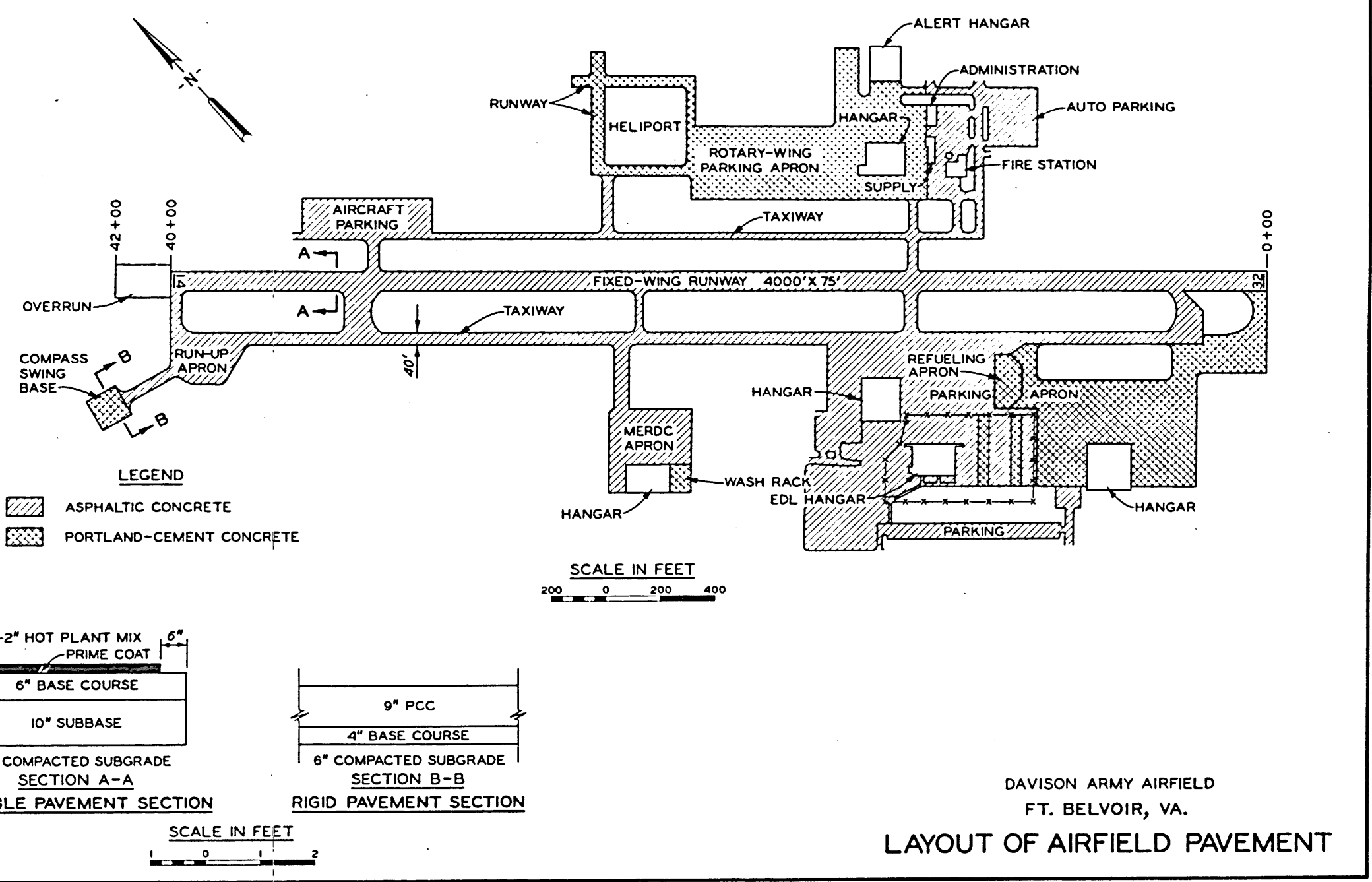

